UDC 141.319.8:17.0"16"

\author{
V. V. KUZMENKO ${ }^{*}$, V. O. BONIAK ${ }^{2 *}$ I. A. SERDIUK ${ }^{3 *}$ \\ 1*Dnipropetrovsk State University of Internal Affairs (Dnipro, Ukraine), e-mail kuzmenko.v.v@gmail.com, \\ ORCID 0000-0002-6725-8765 \\ 2*Dnipropetrovsk State University of Internal Affairs (Dnipro, Ukraine), e-mail valentina.boniak@gmail.com, \\ ORCID 0000-0002-3167-8514 \\ 3*Dnipropetrovsk State University of Internal Affairs (Dnipro, Ukraine), e-mail iserdiuk@ukr.net, \\ ORCID 0000-0002-3655-721X
}

\title{
ANTHROPOLOGICAL SEARCH FOR VALUE ORIENTATIONS OF A NEW CULTURE BY AURELIUS AUGUSTINE
}

Purpose. The article is aimed to reveal the essence of the eternal problem, comprehended by Augustine Aurelius in the culture of the early Middle Ages - the focus of the value orientations of the anthropological search. Theoretical basis. Only in the twentieth century, various aspects of Augustine's creative legacy became the subject of scientific research by many authors. As the direction of their scientific research, the problem of the relationship of reason, faith, knowledge, which has risen sharply in medieval Christian culture, has been considered. The logical outcome of these studies was the assertion that for Augustine Platonism was the main of the philosophical teachings of antiquity; that Augustine, being in line with Christian philosophy, considered the understanding of the aesthetic perfection of the Divine creation of the world as the sense of human life. The analysis of their works gives reason to argue that the definition of the human essence - the Augustine's anthropological problems, was practically not addressed by representatives of domestic and foreign philosophical thought, and therefore remained undiscovered. Originality. The authors have proved that the definition of the human essence by Augustine is in the correlation with his answers to questions about the nature of the origin of man, about the secrets of being, etc. The ethical ideal of the thinker has been revealed, which is systematically formed in his works. Conclusions. The thesis has been substantiated that the anthropological views of Augustine Aurelius are in correlation with his epistemological judgments. Only by knowing the order of things in the universe, determined by the will of the Lord, we will know also the order of our value orientations. The basis of the philosophical comprehension of the human essence by Augustine Aurelius is a series of questions that constantly arise before mankind - about the nature of its appearance, about the secrets of human existence, the sense of life, death and immortality, etc. The ethical ideal of the thinker is an eternal city that is not based on human nature, it is too volatile, therefore it is only to a small extent subject to research, but on a Divine basis the Christian idea.

Keywords: Augustine Aurelius; value orientations of anthropological search; human essence; Law of harmonious Universe; eternal city; church bosom

\section{Introduction}

The appeal to the creative legacy of Aurelius Augustine is especially relevant today. We proceed from the fact that it is this legacy presents and continues from antiquity the anthropological search for the value orientations necessary in any culture and for any religious denomination on planet Earth.

Augustine is rightfully considered one of the founders of the anthropological and ethical constructions of a new culture - Christian, in which, during his work, a new ethic different from the pagan, antique ethics is only emerging. The ethical ideal, formed in the writings of Plato, and then Aristotle, is human self-belief. It is from this position that ancient thinkers consider continuous improvement, including material, of the polis society. However, such improvement, they argue, is impossible without the search for overcoming the human depravity, which is inherent in everyone, as a bodily being. The ethical ideal, which is constantly formed in the 
writings of Augustine - the desire of a person to get rid of vices, respectively - the humility of submission of the material beginning to the spiritual. In this way, the movement of humanity towards the gates of the Kingdom of Heaven becomes possible.

The foregoing indicates that ethical ideas, as well as the anthropological search for ancient thinkers, are sufficiently close to Augustine's ideas and search. He does not reject, but, on the contrary, relies on them, especially in his search for the ways to rid a person of depravity. Accordingly, he should be considered as a thinker of the transition period from pagan antiquity to medieval Christian culture.

Emphasizing the relevance of our study, we note that the anthropological and ethical searches of the thinkers of antiquity, on which Augustine so strongly relied, are an eternal human problem that not only philosophers of various religious confessional orientations are constantly addressing, but also writers until today.

Speaking about the relevance of the research topic, we also note the fact that the work of the church father and now the most authoritative person in the Christian world is holistic. The problem of finding by him the value orientations of humanity is constantly relevant. Modern society with its eternal anthropological problems - the depravity and virtues of man is no exception. We especially emphasize that the prevalence of depravity over virtue is clearly, metaphorically described even during the archaic period in the works of Homer.

In his anthropological search, Augustine considers man as an organic combination of body, soul, and reason. In his treatises, on the one hand, man is presented as a creative act of the Lord, and on the other hand, man is still a vicious creature. However, depravity in man, as Augustine states in the treatise "Confessions", is not from the Lord. It constantly leads people to contention. Augustine particularly vividly discloses the eternal ethical problems of the depravity of people who are endowed with body and reason in the treatise "On the City of God".

In the history of their existence, the inhabitants of planet Earth have always stubbornly used reason for their own vices. Now the period has come when the use of the reason for this purpose poses a direct threat to the existence of all humanity and planet Earth.

Only in the XX-XXI centuries Augustine's legacy in various aspects was investigated by many authors. We give the names of the most significant works, as well as their focus.

The subject of scientific research of M. Li and B. Dessein (2015) is an interpretation of the time phenomenon in the concept of St. Augustine, as well as his contemporary, the Chinese thinker Sen Zhao. The authors substantiate the thesis that Augustine changed the theory of circular time to the linear one. In particular, the theologian interprets "time" both as an objective reality for God, who created time simultaneously with heaven and earth, and as a subjective human reality: for a person, the time when he thinks can only be regarded as "a continuation of thinking".

The representative of Ukrainian philosophical thought A. V. Halapsis (2016), considering the theological roots of the scientific concepts of miracles and the perfection of being, draws attention to the fact that it is St. Augustine who derived from the idea of God's eternity the idea of eternity and the immutability of his will (p. 72).

E. V. Smyslova and L. F. Khabibullina (2016) focused on the problem of free will in medieval theologians Aurelius Augustine and Pelagius-Morgan in a comparative-legal aspect in their work "The problem of free will in "The clockwork testament or: Enderby's end" by A. Burgess". 
A. Nordlander (2019) in his scientific work "The Emergence of Soul: Retrieving Augustine's Potentialism for Contemporary Theological Anthropology" refers to Augustine's creative legacy, which contains an interpretation of the world origin, in particular, the theory of occurrence, as well as two types of potentiality. Considering the problem of the creation of the World, Augustine defines it as incomplete. God's creative potential does not end with the initial creative act of creating the world. God continues to create today, as evidenced by historical potentiality. That which did not exist reappears; that which exists certainly changes its form. Thus, the created world is in constant change. A similar change occurs with a man.

Considering personalism as one of the most influential trends in modern philosophy and theology, rooted in the 17th century, P. V. Khondzinskii (2018) in his work "The Notion of Persona in the Works of St Augustine and the Personalistic Conception of V. I. Nesmelov", draws attention to the fact that this period in history is also called the "Age of Augustine". The scientist believes that it is with the name of this thinker, that an introduction to scientific circulation for the further use of the term "man" is associated. Considering the fact that St. Augustine never defined the semantic meaning of this term, an attempt was made to develop an understanding by the thinker of this concept. This is a scientific study by P. V. Khondzinskii makes it possible to determine the distance between the Augustinians and the modern conceptualization of "personality", in particular, on the example of the early Russian personalist theologian V. I. Nesmelov.

In one of his latest works, «"In the language of sophiology": Priest Sergiy Bulgakov's criticism of St. Augustine's triadology» (Khondzinskii, 2019), the same author compares the positions of Augustine and Thomas Aquinas regarding the Christian faith. In fact, the central idea of the study is to strengthen the dogma of Christian teaching in the period V-XIII centuries.

S. S. Averintsev (1977), B. G. Derevensky (2000), A. F. Losev (1980), A. Men (1998) considered the problem of the relationship of reason, faith, knowledge, the interpretation of knowledge in the modes of faith in medieval Christian culture, which is both a methodological prerequisite and tap into the problem of determining the essence of man at the same time. The authors note that in the writings of Augustine, philosophical and rational-scientific understanding of the physical world, being dependent on the truths of Revelation, turned into an interpretation of the God's word. Later, after the writings of Augustine, this orientation prevailed in the Western Catholic religious thought of the Middle Ages.

According to E. Gilson (1961), N. P. Ivanov (1999), J. Lortz (1999), the main philosophical doctrine of antiquity for Augustine was Platonism. It was the ideas of Plato that had the greatest influence on his anthropological ideas.

The great bishop of Hippo combined the creative power of Tertullian and

the spiritual width of Origen with the ecclesiastical spirit of Cyprian, the

dialectical acuity of Aristotle with the idealistic enthusiasm and profound

speculations of Plato, the Latin spirit of practicalism with the inspired

mobility of the Greeks. (Lortz, 1999, p. 148) 
We emphasize that Augustine laid the foundation of a new philosophy, completed the development line of Latin Christian thought, the prominent representatives of which were Tertullian, Minucius, Cyprian, Arnobius, Lactantius.

V. V. Bolotov (1999), A. V. Sitnikov (2001), N. F. Uskov (2001), V. F. Farrar (2001) suggested that Augustine being in line with Christian philosophy believed that the sense of human life is to comprehend the aesthetic perfection of the divine creation of the world. Such perfection cannot be known solely by reason. The basis of comprehension of the Divine order is faith, which refers more to the will, not to the reason.

As noted by A. F. Losev, N. F. Uskov and others, the writings of St. Augustine clearly reflect the difference between Christian ethics and ethical ideas of ancient Greek philosophers. First, the fact that in his anthropological searches man is represented not in two dimensions, as before: "body" and "soul", but in three: "body", "soul", "spirit" deserves attention. Spirit is a participation in the divine creation through faith in the only God-creator, the openness of man to the divine word, divine wisdom.

Thus, the above-mentioned authors touched on the definition of human essence - the anthropological problem of Augustine in the context of the value orientations of the emerging formation - only indirectly, as part of their own searches, but remained unrevealed. A peculiar lacune in philosophical thought is also the absence in the scientific community of a discussion on the philosophical and anthropological legacy of Augustine, which allows revealing the essence of man.

In view of the foregoing, these problems became the subject of our study.

\section{Purpose}

The article is aimed to reveal the essence of the eternal problem comprehended by Augustine Aurelius in the culture of the early Middle Ages - the focus of the value orientations of the anthropological search.

\section{Statement of basic materials}

It should be noted that Augustine begins the search for human essence only after his epistemological searches. The bishop of Hippo considers a person, as the Creation of the Lord, similar to the world in which he lives. Cognition of human essence is possible from the material beginning to the spiritual beginning. The Universum and the man in it are the creation of the Great Artist. According to Augustine, in the Universum, according to the Great Plan, "order" reigns. Only by knowing it, it becomes possible to know spirituality - a person's belonging to God. Augustine subordinates the categories of "image" and "likeness", which are impossible without ideas about numbers to the abstract category of "order". It is in this sequence of ideas that we see Platonic ideas in the work of Augustine. The universe, like man, was created by the Great Artist, they are harmonious.

It is peculiar to everyone to explore and learn the order of things,

Zenobius; but, at the same time, comprehending and explaining the general order that holds and controls this world is a very difficult and rarely 
feasible business. Moreover, even if someone achieves this, then he cannot achieve another, namely: to find a worthy listener for such divine and mysterious objects, both in virtuous life and in some composition of his scientific knowledge. (Aurelius Augustine, 2000, p. 114)

The cited passage from the treatise "On Order" gives reason to interpret precisely the Platonic vision of a harmonious Universe, which is presented in the Plato's dialogue "Timaeus". According to Plato, the universum is a heavenly stadium that is created by the cosmic mind. The cosmos, in his opinion, is characterized by order; it is eternal and imperishable beauty. Only by knowing the beauty of the cosmos, it becomes possible to know the beauty of the human mind, and then build a model of "correct reasoning", including the state system. Platonic astronomer Timaeus indicates a harmonious circulation of the cosmic mind.

We emphasize that Plato's dialogues are poetic; they have enough cognitive metaphorical constructions, which is why they are subject to interpretation. They reflect the unity of the ontological, epistemological, anthropological views of the ancient thinker.

And yet we pose one more question regarding the cosmos: looking at what kind of prototype did the one who arranged it work - identical and unchanging or having an origin? If the cosmos is beautiful, and its demiurge is good, it is clear that he was looking towards the eternal. If not, which is not lawful for anyone to say, he was looking towards a created. Indeed, it is clear to everybody that he was looking towards the eternal: for the cosmos is the most beautiful of all things created, and the demiurge is the best of all causes. Having been generated in this way, it has been fashioned after that which is grasp by and thought and is selfsame. Again, if these assumptions apply, it is entirely necessary that this cosmos is the image of something. But in every discourse, it is important to choose a nature-appropriate beginning. (Plato, 1994, p. 432)

The dialogue "Timaeus", considers the first beginning of all things and its creator - the demiurge. It is emphasized that time arose together with the created Universe. The ancient thinker also points to the cosmic essence of man. His body and soul were created by the 
demiurge along with the universe. Plato points that human body is just as harmonious, as is the body of the Universe. In the dialogue "Timaeus" we interpret that only by knowing the demiurge's plan for the structure of the Universe, it becomes possible to know the human essence and only then construct a fair social system.

Let us note dear reader that the ideas that are presented in the early works of Augustine, in many respects coincide with the ideas that are demonstrated in the late works of Plato.

According to Augustine, Plato came very close to the ideas of Christianity. The world of unchanging, eternal ideas of Plato leads him to an understanding of the divine, that which is comprehensible only by reason. According to Augustine, it was Plato, who created the perfect philosophy system.

Plato thus added to what he already possessed of Socratic charm and subtlety in moral matters, the knowledge of things human and divine diligently learned from the men just mentioned. He crowned these elements with a discipline capable of organizing and judging them, namely, dialectic, which is, he thought, wisdom itself, or at least that without which wisdom is impossible, and he composed thereby the perfect philosophy. (Aurelius Augustine, 2000, p. 79)

In the search for the essence of man to determine the value orientations of the emerging society, Augustine completely departs from Greek rationalism. In his interpretation, the will, but not the reason, is among the causal relationships that determine the order in society. Moreover, the will of man, as the creation of the Lord, is submitted entirely to the will of God.

But it does not follow that, though there is for God a certain order of all causes, there must therefore be nothing depending on the free exercise of our own wills, for our wills themselves are included in that order of causes which is certain to God, and is embraced by His foreknowledge, for human wills are also causes of human actions; and He who foreknew all the causes of things would certainly among those causes not have been ignorant of our wills. (Aurelius Augustine, 1998, p. 206)

From the above passage of the treatise "On the City of God", we can conclude that the anthropological views of Augustine are in correlation with his epistemological views. Only by 
knowing the order of things determined by the will of God, we know the order of things that are determined by our will too, respectively, the order of our value orientations.

The soul, according to Augustine, is not material. But it has the property of thinking. However, according to Augustine, it is the soul of human, which is close to God as a nonmaterial substance. The Hippo thinker claims that it is the soul that cognizes God who created the world with all its causal relationships. Man, as the creation of the Lord, is always identical only to himself. Each person has his own soul and will, his own memory inherent only in him. According to Augustine, from the identity of man to himself, the wealth of the spirit is contained only in his soul.

And first of all, indeed, light was made by the word of God, and God, we read, separated it from the darkness, and called the light Day, and the darkness Night; but what kind of light that was, and by what periodic movement it made evening and morning, is beyond the reach of our senses; neither can we understand how it was, and yet must unhesitatingly believe it. (Aurelius Augustine, 1998, p. 471)

Speaking about the inseparability of the anthropological searches of Augustine and his epistemological searches, we note the fact that the epistemology of Augustine is a priori, he emphasizes the superiority of faith over reason. However, in his understanding, the source talking about the truth is the Holy Church. Only it pronounces the truth, to which the immortal human soul should be attached.

In Augustine's anthropology, we are talking about the resurrection of people. Such a resurrection will occur in the integrity of the soul and body. The resurrection, according to the bishop of Hippo, will take place only by the will of God.

And so there are indeed many bodies of Christians lying unburied; but no one has separated them from heaven, nor from that earth which is all filled with the presence of Him who knows whence He will raise again what He created. It is said, indeed, in the Psalm: "The dead bodies of Thy servants have they given to be meat unto the fowls of the heaven, the flesh of Thy saints unto the beasts of the earth. Their blood have they shed like water round about Jerusalem; and there was none to bury them" (Ps. LXXVIH, 2, 3). But this was said rather to exhibit the 
cruelty of those who did these things, than the misery of those who suffered them. (Aurelius Augustine, 1998, p. 21)

Dead people will rise in their prime. But the bodies of the saints will be much more perfect than the human bodies. Although the bodies of people will be able to move in space. Let us note that the theory of the totality of bodily and spiritual resurrection is an interpretation of the Easter resurrection of Christ. Moreover, in Augustine's view, the infinite, immortal soul always controls the body. Speaking of infinity, in the treatise "On the City of God" the Hippo bishop emphasizes that God created the world in time, and together with the time. Intelligent human souls are part of this world. However, speaking of the reason in the soul, Augustine does not claim that the reason is able to save the soul from depravity, let us recall, according to the logical constructions of Augustine, the soul is controlled by will. Thus, it is precisely from the anthropological constructions of Augustine that his value orientations of the emerging new formation in society result.

Dear reader, let us note that Augustine does not aims to investigate the idea of the human essence that appears in the era of early Christianity, moreover, to highlight the similarity of his essence with either the first biblical man Adam or Christ. Augustine sees man as a creature living in the bosom of the church, scrupulously attending to church commandments as laws. Augustine constructs the essence of a man who certainly loves God. However, God does not love every person. In "Confessions" the reader is presented only with the process of man's search for Divine love. The Hippo thinker argues each must have a sincere love for God, the desire to "possess" God, it is necessary, he argues, "to live in God".

In our opinion, this recalls the principle of the relationship of the Roman state to its citizens through the law. We emphasize that the category "order" is decisive in the writings of Augustine Aurelius.

Let us note that the contradictions in the work of Augustine in identifying the human essence appear, firstly, in relation to the physical nature of man, and in the relationship between the soul, which possibly contains sin and spiritual involvement in God; secondly, in the gap between the philosophical comprehension of man, which is based on a number of questions, namely: about the nature of his appearance; about the secrets of human existence, the meaning of life, death and immortality, as well as many others.

We emphasize especially that the ideal of Augustine Aurelius is an eternal city that is not based on human nature, it is too volatile, therefore it is only slightly subject to research, but on a Divine basis - the Christian idea. That is why it is necessary for each person to move into the bosom of the church.

We believe that Augustine's system is special, it is world-contemplative. It cannot be considered only philosophical, it is apologetic, justifying Christianity, but very close to philosophical, in particular - cognitive. His apologetics is different from early apologetics. He reflects on the essence of man, trying to reveal his nature, as well as on what is the World order.

The world order is built by God as a reliable, consistently created structure. About this Hippo priest repeatedly speaks in his works. Dear reader, let us recall, I. Newton writes that he cognizes the Divine order in the world created by God much later in the "Mathematical Principles of Natural Philosophy". In our opinion, Augustine Aurelius in his various treatises, in particular 
"On Order", in "Confessions" is engaged in cognitive activity in relation to the Divine creation, the World in which he lives. The World is eternal reality, eternal harmony. Man, in his understanding, is a creature, but still endowed with sin. It is man, his nature, he only contemplates, but the World he tries to cognize.

We believe that Augustine Aurelius precisely in the anthropological context requires a man to comprehend the world harmony and follow it. In his understanding Harmony in the World was created by God, and its opposite - human sinfulness is a different force.

The treatise "On the City of God" demonstrates that a person who is changeable in his essence follows the force in which he contemplates the greatest benefit.

We note that in the anthropological contemplation of Augustine Aurelius, such an indefinite concept as human freedom is viewed from a negative perspective. The salvation of man is in his deliverance from freedom. Let us recall that since antiquity, since the works of Plato freedom, as one of the components is included in the "natural right" of man. However, the ancient thinker did not provide a definition of "freedom". We emphasize that we can consider the definition of this term in Plato through various cognitive metaphors, such as, for example, the image of the chariot in the "Phaedrus" dialogue. Note that "freedom" in this dialogue is not represented as "good".

In connection with the foregoing, we emphasize that in his anthropological search Augustine Aurelius indicates that "evil" defines the essence of man, but his salvation is only in the powers of God. According to Augustine, forcibly being in the bosom of the church, humanity can acquire virtues, come to "unity in Christ". The eternal law of harmonious World was created by God. God's relation to the creature of man is a part of the law of the harmonious World.

In the anthropological search for the value orientations of the Hippo bishop, several main categories were used, namely: "freedom", "evil", "grace", "eternal law", "unity with God". The last of them implies unity, not forcible, but internal, it is a person's coming to grace, his affirmation in human society. Accordingly, it is this concept, which appeared naturally, but not forcibly, should be interpreted as the category of "freedom".

In our opinion it is this freedom that Augustine considers it in "Confessions", a treatise that arose at the turn of Antiquity and the Middle Ages. It is in this work that the communication of man with God is described. "Freedom" according to Augustine is love for God, but at the same time, cognition of the Divine essence. In this treatise, Augustine reflects on the solitude of the human soul. It is free, and therefore happy, in spiritual communication with its Creator.

Dear reader let us note that according to Augustine, Divine cognition is something higher sacred. In this context, there is reason to argue that Augustine, speaking of the process of knowing God, is likened to Plato; he speaks of knowing the idea of God through knowing himself. According to Plato, "know yourself, and you will know the world around you"; according to Augustine, "the law of God is within every man"; and according to Plato and Augustine, the knowledge of the World becomes possible only in solitude, if and only if a person delves into his own soul, begins to contemplate himself.

Speaking of the category of "freedom", Augustine claims that every person is created by God free, therefore he is responsible for his choice, which relates to good and evil. The choice in favor of evil is a sinful illness of the soul. Thus, the human soul in the work of Augustine should be interpreted as "involvement in God". But the spirit, as volatility, should be discarded along with the flesh in the process of cognitive activity. 
Once again, we emphasize that if Plato offers self-knowledge as a necessary component for knowing the World around him, Augustine to know the World recognizes it necessary not only knowing himself, but also knowing the Divine essence and its laws, since the World is created and man is created. In this case, knowing oneself is an internal process, it requires solitude, and knowledge of the Law of God becomes possible only in the church bosom.

However, we note in the culture of late Antiquity, or rather, the early Middle Ages, reflecting on the essence of man, Augustine laid the concept of human death. Death is inevitable, it is quick, and in this, it is different from life. According to Augustine, a person is able to exist without a material body. Moreover, he does not consider the body like Aristotle - the dungeon of the soul. In their union, the soul and body create an individual personality, although it is the human body that is sinful. However, being in the body and expecting death is an expectation of the Divine grace. It is being in a physical state that the soul is capable of absorbing the possible ills that are around it. But only by getting rid of the body does a person essentially acquire a state between the temporal and angelic worlds.

Speaking about the human essence, Augustine considers it from the perspective of late apologetics. He is more interested in knowing it. In particular, this refers to his description of the state of each of the seven degrees of the soul. The first and second do not separate a person from plants and animals, but each subsequent brings him closer to God. According to Augustine, not everyone is capable of achieving the seventh degree. This is the contemplation of truth. Recall, dear reader that Antiquity is completely far from such reasoning.

\section{Originality}

The authors substantiated that the anthropological views of Augustine Aurelius are in correlation with his epistemological views. The ethical ideal is revealed, which is systematically formed in his works. It is demonstrated that in the search for the human essence of a developing society, Augustine completely departs from Greek rationalism. It is shown that man, as the creation of God, is always identical only to himself.

\section{Conclusions}

The anthropological views of Augustine Aurelius are in correlation with his epistemological views. Only by knowing the order of things, determined by the will of the Lord, we will also know the order of our value orientations. Accordingly, the basis of the philosophical comprehension of the human essence by Augustine Aurelius is a series of questions that constantly arise before mankind - about the nature of its appearance, about the secrets of human existence, the sense of life, death and immortality, as well as many others. The ethical ideal of the thinker is an eternal city that is not based on human nature, it is too volatile, therefore it is only to a small extent subject to research, but on a Divine basis - the Christian idea.

In the anthropological search for the value orientations of the Hippo bishop, several main categories were used, among them are "freedom", "evil", "grace", "eternal law", "unity with God". The last of them implies unity, not forcible, but internal, it is a person's coming to grace, his affirmation in human society. It is this concept, which appeared naturally, but not forcibly, should be interpreted as the category of "freedom".

We emphasize, Augustine Aurelius in his anthropological search indicates that "evil" determines the essence of man; his salvation is only in the power of God. According to 
Augustine, forcibly being in the bosom of the church, mankind can acquire virtues, come to "unity in Christ". The eternal law of harmonious World was created by God. God's relation to the creature of man is a part of the law of the harmonious World.

The treatise "On the City of God" demonstrates that a person who is volatile in his essence follows the force in which he contemplates the greatest benefit.

The ideal of Augustine Aurelius is an eternal city that is not based on human nature, it is too volatile, therefore it is only slightly subject to research, but on a Divine basis - the Christian idea. That is why it is necessary for each person to move into the bosom of the church.

\section{REFERENCES}

Aurelius Augustine (Blazhennyy). (1998). V Grade Bozhiyem. In Tvoreniya (Vol. 3). St. Petersburg: Aleteyya; Kyiv: UTsIMM-Press. (in Russian)

Aurelius Augustine (Blazhennyy). (2000). Ob istinnoy religii. In Tvoreniya (Vol. 1). St. Petersburg: Aleteyya; Kyiv: UTsIMM-Press. (in Russian)

Averintsev, S. S. (1977). Literaturnye teorii v sostave srednevekovogo tipa kultury. Moscow: Nauka. (in Russian)

Bolotov, V. V. (1999). Ucheniye Origena o Svyatoy Troitse. In Sobraniye tserkovno-istoricheskikh trudov (Vol. 1). Moscow: Martis. (in Russian)

Derevensky, B. G. (2000). Uchenie ob Antikhriste v drevnosti i srednevekove. St. Petersburg: Aleteya. (in Russian)

Farrar, V. F. (2001). Zhizn i trudy svyatykh ottsov (Vol. 1). Moscow: Izdanie Sretenskogo monastyrya. (in Russian)

Gilson, E. (1961). The Christian philosophy of Saint Augustine. London; Cambridge. (in English)

Halapsis, A. (2016). Miracles and the perfection of being: The theological roots of scientific concepts. Anthropological Measurements of Philosophical Research, 9, 70-77. doi: https://oi.org/10.15802/ ampr2016/72235 (in Russian)

Ivanov, N. P. (1999). Skazal Bog ... Bibleyskaya ontologiya i bibleyskaya antrtopologiya. Klin: Izd. fond "Khristianskaya zhyzn". (in Russian)

Khondzinskii, P. (2018). The Notion of Persona in the Works of St Augustine and the Personalistic Conception of V. I. Nesmelov. Voprosy Filosofii, 7, 187-195. doi: https://doi.org/10.31857/S004287440000240-9 (in Russian)

Khondzinskii, P. (2019). "In the language of Sophiology": Priest Sergiy Bulgakov’s criticism of St. Augustine’s Triadology. St. Tikhon's University Review. Series I: Theology. Philosophy. Religious Studies, 83, 11-25. doi: https://doi.org/10.15382/sturi201983 (in Russian)

Li, M., \& Dessein, B. (2015). Aurelius Augustinus and Seng Zhao on "Time": An Interpretation of the Confessions and the Zhao Lun. Philosophy East and West, 65(1), 157-177. doi: https://doi.org/10.1353/pew.2015.0019 (in English)

Lortz, Y. (1999). Istoriya tserkvi, rassmotrennaya v svyazi s istoriyey idey (Vol. 1). Moscow: Khristianskaya Rossiya. (in Russian)

Losev, A. F. (1980). Istoriya antichnoy estetiki. Pozdniy ellinizm (Vol. 6). Moscow: Iskusstvo. (in Russian)

Men, A. (1998). Istoriya religii. V poiskakh Puti, Istiny i zhyzni (Vol. 1). Moscow: Forum-Infra. (in Russian)

Nordlander, A. (2019). The Emergence of Soul: Retrieving Augustine's Potentialism for Contemporary Theological Anthropology. Modern Theology, 35(1), 122-137. doi: https://doi.org/10.1111/moth.12443 (in English)

Plato. (1994). Sobraniye sochineniy v 4 t. (Vol. 3, pp. 432-433). Moscow: Mysl. (in Russian)

Sitnikov, A. V. (2001). Filosofiya Plotina i traditsii khristianskoy patristiki. St. Petersburg: Aleteya. (in Russian)

Smyslova, E. V., \& Khabibullina, L. F. (2016). The problem of free will in "the clockwork testament or: Enderby's end" by A. Burgess. The Turkish Online Journal of Design, Art and Communication, 6, 2626-2631. (in English)

Uskov, N. F. (2001). Khristianstvo i monashestvo v Zapadnoy Yevrope rannego srednevekovya. Germanskie zemli II/III-serediny XI v. St. Petersburg: Aleteya. (in Russian)

\section{LIST OF REFERENCE LINKS}

Аврелий Августин (Блаженный). Творения : В 4 т. / Аврелий Августин (Блаженный). - Санкт-Петербург : Алетейя ; Киев : УЦИММ-Пресс, 1998. - Т. 3 : О Граде Божием. - 595 с. 
Аврелий Августин (Блаженный). Творения : В 4 т. / Аврелий Августин (Блаженный). - Санкт-Петербург : Алетейя ; Киев : УЦИММ-Пресс, 2000. - Т. 1 : Об истинной религии. - 742 с.

Аверинцев, С. С. Литературные теории в составе средневекового типа культуры / С. С. Аверинцев. - Москва : Наука, 1977. - 450 с.

Болотов, В. В. Собрание церковно-исторических трудов / В. В. Болотов. - Москва : Мартис, 1999. - Т. 1 : Учение Оригена о Святой Троице - 583 с.

Деревенский, Б. Г. Учение об Антихристе в древности и средневековье / Б. Г. Деревенский. - СанктПетербург : Алетейя, 2000. - 528 с.

Фаррар, В. Ф. Жизнь и труды святых отцов: в 2-х т. / В. Ф. Фаррар. - Москва : Издание Сретенского монастыря, 2001. - Т. 1. -670c.

Gilson, E. The Christian philosophy of Saint Augustine / E. Gilson. - London ; Cambridge, 1961. - 269 p.

Халапсис, А. Чудеса и совершенство бытия: теологические корни научных концепций / А. Халапсис // Антропологічні виміри філософських досліджень. - 2016. - Вип. 9. - С. 70-77. doi: https://doi.org/ 10.15802/ampr2016/72235

Иванов, Н. П. Сказал Бог ... Библейская онтология и библейская антропология / Н. П. Иванов. - Клин : Изд. фонд "Христианская жизнь", 1999. - 120 с.

Хондзинский, П. Понятие persona в наследии блж. Августина и персоналистическая концепция В. И. Несмелова / П. Хондзинский // Вопросы философии. - 2018. - №. 7. - Р. 187-195. doi: https://doi.org/10.31857/S004287440000240-9

Хондзинский, П. "На языке софиологии": критика о. Сергием Булгаковым триадологии блаженного Августина / П. Хондзинский // Вестник Православного Свято-Тихоновского гуманитарного университета, Серия I: Богословие. Философия. Религиоведение. - 2019. - Вып. 83. - С. 11-25. doi: https://doi.org/10.15382/sturi201983

Li, M. Aurelius Augustinus and Seng Zhao on "time": an interpretation of the confessions and the Zhao Lun / M. Li, B. Dessein // Philosophy East and West. - 2015. - Vol. 65. - № 1. - 157-177. doi: https://doi.org/ 10.1353/pew.2015.0019

Лортц, Й. История церкви, рассмотренная в связи с историей идей : в 2-х т. / Й. Лортц. - Москва : Христианская Россия, 1999. - Т. 1.- 511 с.

Лосев, А. Ф. История античной эстетики. Поздний эллинизм : в 8-х т. / А. Ф. Лосев. - Москва : Искусство, 1980. - T. 6. - $720 \mathrm{c}$.

Мень, А. История религии. В поисках Пути, Истины и жизни: в 2-х т. / А. Мень. - Москва : Форум-Инфра, 1998. - T. 1. $-216 \mathrm{c}$.

Nordlander, A. The Emergence of Soul: Retrieving Augustine's Potentialism for Contemporary Theological Anthropology / A. Nordlander // Modern Theology. - 2019. - Vol. 35, Iss. 1. - P. 122-137. doi: https://doi.org/10.1111/moth.12443

Платон. Собрание сочинений в 4 т. / Платон. - Москва : Мысль, 1994. - Т. 3. - С. 432-433.

Ситников, А. В. Философия Плотина и традиции христианской патристики / А. В. Ситников. - СанктПетербург : Алетейя, 2001. - 242 с.

Smyslova, E. V. The problem of free will in the "clockwork testament or: enderby's end" by A. Burgess / E. V. Smyslova, L. F. Khabibullina // The Turkish Online Journal of Design, Art and Communication. 2016. - Vol. 6. - P. 2626-2631.

Усков, Н. Ф. Христианство и монашество в Западной Европе раннего средневековья. Германские земли II/III-середины XI в. / Н. Ф. Усков. - Санкт-Петербург : Алетейя, 2001. - 506 с.

\section{В. В. КУЗЬМЕНКО ${ }^{1 *}$, В. О. БОНЯК ${ }^{2 *}$, І. А. СЕРДЮК ${ }^{3 *}$}

${ }^{1 *}$ Дніпропетровський державний університет внутрішніх справ (Дніпро, Україна), ел. пошта kuzmenko.v.v@gmail.com, ORCID 0000-0002-6725-8765

${ }^{2 *}$ Дніпропетровський державний університет внутрішніх справ (Дніпро, Україна), ел. пошта valentina.boniak@gmail.com, ORCID 0000-0002-3167-8514

3* Дніпропетровський державний університет внутрішніх справ (Дніпро, Україна), ел. пошта iserdiuk@ukr.net, ORCID 0000-0002-3655-721X 


\section{АНТРОПОЛОГІЧНИЙ ПОШУК ЦІННІСНИХ ОРІЕНТИРІВ НОВОЇ КУЛЬТУРИ АВРЕЛІЕМ АВГУСТИНОМ}

Мета. Розкрити пізнавану Августином Аврелієм у культурі раннього середньовіччя сутність вічної проблеми - спрямованість ціннісних орієнтирів антропологічного пошуку. Теоретичний базис. Різні аспекти творчого спадку Августина лише у XX столітті стали предметом наукових пошуків багатьох авторів. Як напрямок іх наукових пошуків розглядалась проблема відношення розуму, віри, знань, що гостро постала у середньовічній християнській культурі. Логічним підсумком цих досліджень стали твердження про те, що з філософських учень античності головним для Августина був платонізм; що Августин, перебуваючи в руслі християнської філософії, сенсом людського життя вважав осягнення естетичної досконалості Божественного творення світу. Здійснений аналіз їх праць дає підстави стверджувати те, що визначення сутності людини - антропологічна проблематика Августина, представниками вітчизняної та зарубіжної філософської думки практично не досліджувалась, а тому залишилась не розкритою. Наукова новизна. Авторами доведено, що визначення сутності людини Августином Аврелієм знаходиться у взаємозв'язку з його відповідями на питання про природу появи людини, про таємниці буття й ін. Розкрито етичний ідеал мислителя, що системно формується в його працях. Висновки. Обгрунтовано тезу про те, що антропологічні погляди Августина Аврелія знаходяться у взаємозв'язку з його гносеологічними судженнями. Лише пізнавши порядок речей в універсумі, визначений волею Господа, ми пізнаємо і порядок наших ціннісних орієнтирів. В основі філософського осягнення сутності людини в Августина Аврелія знаходиться низка питань, що постійно постають перед людством про природу його появи, про таємниці людського буття, сенс життя, смерті та безсмертя й ін. Етичний ідеал мислителя - вічне місто, що засноване не на природі людській, вона надто мінлива, тому лише незначною мірою підлягає дослідженню, але на Божественній основі - християнській ідеї.

Ключові слова: Августин Аврелій; Платон; ціннісні орієнтири антропологічного пошуку; сутність людини; природа людини; Закон гармонійного Світу; вічне місто

\section{В. В. КУЗЬМЕНКО ${ }^{1 *}$, В. А. БОНЯК ${ }^{2 *}$, И. А. СЕРДЮК ${ }^{3 *}$}

1 *Днепропетровский государственный университет внутренних дел (Днипро, Украина), эл. почта kuzmenko.v.v@gmail.com, ORCID 0000-0002-6725-8765

$2 *$ Днепропетровский государственный университет внутренних дел (Днипро, Украина), эл. почта valentina.boniak@gmail.com, ORCID 0000-0002-3167-8514

3*Днепропетровский государственный университет внутренних дел (Днипро, Украина), эл. почта iserdiuk@ukr.net, ORCID 0000-0002-3655-721X

\section{АНТРОПОЛОГИЧЕСКИЙ ПОИСК ЦЕННОСТНЫХ ОРИЕНТИРОВ НОВОЙ КУЛЬТУРЫ АВРЕЛИЕМ АВГУСТИНОМ}

Цель. Раскрыть осмысливаемую Августином Аврелием в культуре раннего средневековья сущность вечной проблемы - направленность ценностных ориентиров антропологического поиска. Теоретический базис. Различные аспекты творческого наследия Августина лишь в XX столетии стали предметом научных поисков многих авторов. В качестве направления их научных изысканий рассматривалась проблема отношения разума, веры, знания, остро вставшая в средневековой христианской культуре. Логическим итогом этих исследований стали утверждения о том, что из философских учений античности главным для Августина был платонизм; что Августин, находясь в русле христианской философии, считал смыслом человеческой жизни постижение эстетического совершенства Божественного творения мира. Проведенный анализ их работ дает основание утверждать, что определение сущности человека - антропологическая проблематика Августина, - представителями отечественной и зарубежной философской мысли практически не затрагивалась, а потому осталась не раскрытой. Научная новизна. Авторами доказано, что определение сущности человека Августином Аврелием находится во взаимосвязи с его ответами на вопросы о природе появления человека, о тайнах бытия и др. Раскрыт этический идеал мыслителя, системно формирующийся в его трудах. Выводы. Обоснован тезис о том, что антропологические воззрения Августина Аврелия находятся во взаимосвязи с его гносеологическими суждениями. Лишь познав порядок вещей в универсуме, 
определённый волей Господа, мы познаем и порядок наших ценностных ориентиров. В основе философского постижения сущности человека у Августина Аврелия находится ряд постоянно возникающих перед человечеством вопросов - о природе его появления, о тайнах человеческого бытия, смысла жизни, смерти и бессмертия и др. Этический идеал мыслителя - вечный город, который зиждется не на природе человеческой, она слишком изменчива, поэтому лишь в незначительной мере подлежит исследованию, но на Божественной основе - христианской идее.

Ключевые слова: Августин Аврелий; ценностные ориентиры антропологического поиска; сущность человека; Закон гармоничного Мира; вечный город; церковное лоно

Received: 18.07.2019

Accepted: 22.11.2019 